Authors' version of the article published in Environmental Technology, 11 (3), 239-248 (1990)

and available a DOI: 10.1080/09593339009384862

\title{
TREATMENT OF TEREPHTHALIC ACID PLANT WASTEWATER WITH AN ANAEROBIC FIXED FILM REACTOR
}

A. Noyola ${ }^{1}$. H. Macarie, J.-P. Guyot ${ }^{2}$

Universidad Autónoma Metropolitana, Departamento de Biotecnología, A.P. 55-535, Iztapalapa, 09340 México D.F., México

${ }^{1}$ Instituto de Ingeniería UNAM, A. P. 70472, Coyoacan, 04510 México, D.F., México.

${ }^{2}$ Mission ORSTOM, Homero 1804-404, los Morales 11510, México, D.F., México.

\section{ABSTRACT}

Anaerobic treatment of terephthalic acid plant wastewater with a lab-scale downflow tubular fixed film reactor achieved $75 \%$ of COD removal with a HRT of 3.4 days at $33^{\circ} \mathrm{C}$. The raw wastewater from a petrochemical plant was settled and neutralized prior to reactor feeding. The responses to shock loads and to periods without feeding were satisfactory, and no inhibitory effects were noticed. A primary settling - anaerobic - aerobic process configuration is proposed as a highly efficient, energy saving alternative to the conventional aerobic process.

\section{INTRODUCTION}

Polymer grade terephthalic acid (1,4-benzenedicarboxylic acid) is essentially used to make poly (ethylene terephthalate), the basic polymer employed in the manufacture of polyester textile fibers, polyester films (X-ray films, microfilms, audio and video recording tapes), food packaging, beverage bottles, adhesives, coatings etc. (1). This compound is produced in the USA, Japan, Western and Eastern Europe, Latin America and Southeast Asia. In 1986, 4.2 millions tons were manufactured (2), and since this time, the production capacity of several plants have been increased and new plant projects have been announced or realized.

The wastewater from factories producing terephthalic acid 
is generally treated by three stage activated sludge process (3). This arrangement allows good total COD removal (more than 90\%) and it has proved to be resistant to shocks of twice the normal organic load when treating a synthetic wastewater simulating an effluent from terephthalic acid plants (3). In addition, it has been reported that terephthalate and p-toluate (both at COD = $\left.1000 \mathrm{mg} \cdot \mathrm{l}^{-1}\right)$, which are the principal aromatic contaminants of this effluent, were degraded in fed batch activated sludge reactors to $96 \%$ and $88 \%$ respectively (4).

However, the aerobic treatment of this kind of wastewater presents two principal disadvantages: high $\mathrm{O}_{2}$ (energy) requirements and poor settling sludge (3) or even bulking sludge (5). Furthermore, the terephthalic acid plant effluent has deficiencies in nitrogen and phosphorus; these elements must be added at a ratio of 200:5:1 (COD:N:P) for aerobic treatment, which means important ammonia and phosphoric acid consumption.

Compared with aerobic treatment, the anaerobic process has lower nutrient requirements and sludge production, and it may be an energy producer. In addition, if second or third generation reactors are employed for high strength wastewater treatment, plant size can be smaller than in aerobic systems. Anaerobic reactors are mainly applied to food processing industry effluents which are readily biodegradable. Nevertheless, various studies prove the feasibility of anaerobic digestion in treating chemical wastewaters such as those from coal gasification, paint stripping operations, refinery sour water stripper bottoms (6), coal liquefaction (7), coal coking (8), manufacture of ethylene and propylene from naphta (9) production of polyolefins, pharmaceutical intermediates and acrylic resins (10). Moreover, two full scale upflow anaerobic sludge blanket (UASB) reactors have been reported in the Netherlands to treat effluents containing phenol, toluene, benzene and benzoic acid (11).

In addition, a work on subsurface injection of wastewater from a dimethyl terephthalate plant, which is somehow similar to terephthalic acid wastewater, found methanogenic activity in aquifers (12), where the waste was highly diluted. This result suggested that terephthalic plant effluent might be anaerobically degraded. In fact, a previous study (13) with two UASB reactors fed with the same wastewater utilized in this 
work, reached $46.4 \%$ on COD removal with 2.7 days of HRT. However, this low efficiency led us to study another type of anaerobic reactor.

In this work, we present results from the anaerobic treatment of a terephthalic acid plant wastewater using a tubular fixed film reactor, in order to assess its feasibility as an alternative to the energy consuming aerobic process.

\section{MATERIAL AND METHODS}

Reactor design. The laboratory scale fixed film reactor (Fig. 1) was made with a plexiglass column of $100 \mathrm{~cm}$ high and $9.6 \mathrm{~cm}$ internal diameter, packed with PVC tubes $67 \mathrm{~cm}$ high and $1.27 \mathrm{~cm}$ of diameter. The tubes provided $1.05 \mathrm{~m}^{2}$ of support area (specific surface area: $221 \mathrm{~m}^{2} / \mathrm{m}^{3}$ ) and a void volume of $4.75 \mathrm{l}$. The reactor was fed in a downflow pattern with a peristaltic pump. The influent wastewater was kept at $6^{\circ} \mathrm{C}$ under mixing. Biogas was evacuated at the top of the column and directed to a gas meter device filled with acidified brine $(\mathrm{pH}<4)$. The system was kept at $33 \pm 2{ }^{\circ} \mathrm{C}$.

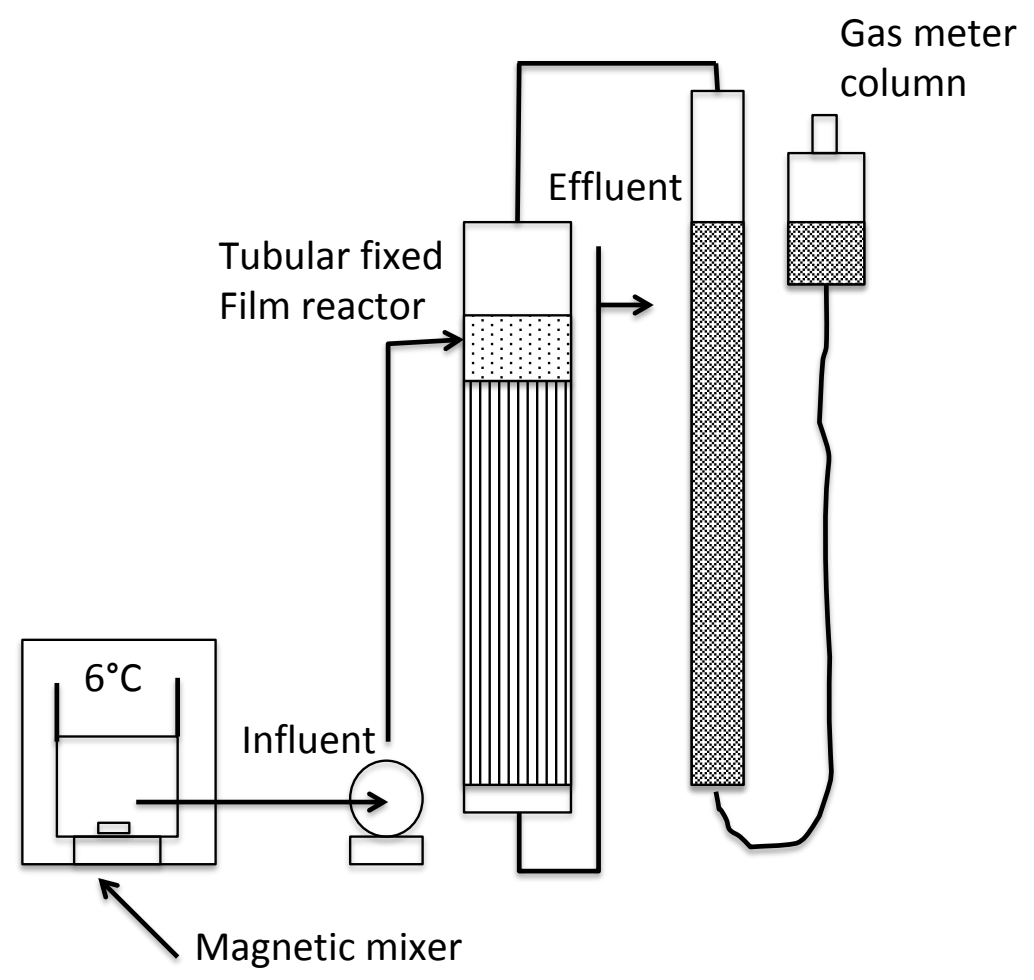

Fig.1 Schematic diagram of the experimental arrangement 
Wastewater characteristics. The water used in this study was obtained from a Purified Terephthalic Acid (PTA) factory. Raw wastewater was weekly sampled at the entrance of the activated sludge treatment system of the PTA plant, after nutrient ( $\mathrm{N}$ and $\mathrm{P}$ ) addition. Table 1 shows a characterization of the wastewater, with the main aromatic compounds found in the mother liquor (liquid waste from the purification unit), which is an important constituent of the raw wastewater.

Table 1. Characteristics of the wastewater

\begin{tabular}{|c|c|}
\hline Parameter & Concentration \\
\hline Raw wastewater & \\
\hline $\mathrm{pH}$ & 4.5 \\
\hline $\mathrm{COD}$ & $9500 \mathrm{mg} \mathrm{l}^{-1}$ \\
\hline $\mathrm{BOD}_{5}$ & $5500 \mathrm{mg} \mathrm{l}^{-1}$ \\
\hline TSS & $2200 \mathrm{mg} \mathrm{l}^{-1}$ \\
\hline Acetic acid & $1000 \mathrm{mg} \mathrm{l}^{-1}$ \\
\hline Mother Liquor* & \\
\hline Terephthalic acid (PTA) & $2670 \mathrm{mg} \mathrm{l}^{-1}$ \\
\hline p-toluic acid & $480 \mathrm{mg} \mathrm{l}^{-1}$ \\
\hline Benzoic acid & $354 \mathrm{mg} \mathrm{l}^{-1}$ \\
\hline 4-formylbenzoic acid & $20 \mathrm{mg} \mathrm{l}^{-1}$ \\
\hline
\end{tabular}

* supernatant after 10 min sedimentation

At first, the high content of fast settling suspended solids in the raw wastewater and the low feed rate did not permit homogeneous feeding of the reactor. In spite of a mixing storage vessel, the plastic tubing of the peristaltic pump clogged frequently, so it was decided to decant the raw wastewater before feeding. This settled wastewater was neutralized to $\mathrm{pH} 6.15$ with $\mathrm{NaHCO}_{3}$ and used to feed the reactor. A characterization of the influent, after neutralization, is presented in Table 2.

Start-up and operation. The reactor had already developed biofilm on the tubular support during a previous study (14) using anaerobically adapted activated sludge from a municipal plant as seed. The reactor was filled with tap water and settled wastewater (1:1) and feeding started immediately at a HRT of 10 days (organic load of $0.67 \mathrm{~kg}$ 
COD $\mathrm{m}^{-3} \mathrm{~d}^{-1}$ ) during three weeks in order to start sludge acclimation. Then, the reactor was fed at two different HRT: 5.8 days from day 21 to 87 and 3.4 days from day 88 to 164 (1.08 and $1.89 \mathrm{~kg} \operatorname{COD~\mathrm {m}^{3}} \mathrm{d}^{-1}$ of organic load. respectively).

Table 2. Characteristics of the influent

\begin{tabular}{|c|c|c|c|c|c|c|}
\hline \multirow[b]{2}{*}{ PARAMETER } & \multicolumn{5}{|c|}{ PERIOD } & \multirow[b]{2}{*}{$\mathrm{d}_{\mathrm{s}}$} \\
\hline & $\begin{array}{l}\text { HRT } \\
\text { mean }\end{array}$ & $\begin{array}{ll}5.8 & d\end{array}$ & $d_{s}$ & $\begin{array}{l}\text { HRT } \\
\text { mean }\end{array}$ & $\begin{array}{l}3.4 \\
n\end{array}$ & \\
\hline Alk. $\left(\operatorname{mg~} \mathrm{CaCO}_{3} \mathrm{l}^{-1}\right)$ & 2034 & 20 & 958 & 1967 & 18 & 315 \\
\hline COD total (mg $\left.1^{-1}\right)$ & 6260 & 23 & 1309 & 6340 & 20 & 367 \\
\hline COD soluble $\left(\mathrm{mg} 1^{-1}\right)$ & 5818 & 14 & 1234 & 5764 & 16 & 423 \\
\hline $\mathrm{N}-\mathrm{NH}_{4}^{+} \quad\left(\mathrm{mg} \mathrm{l} l^{-1}\right)$ & 97 & 10 & 36.7 & 113 & 12 & 21.2 \\
\hline $\operatorname{TS}\left(\mathrm{mg} l^{-1}\right)$ & 6753 & 11 & 1659 & 5900 & 13 & 191 \\
\hline $\operatorname{TVS} \quad\left(\mathrm{mg} 1^{-1}\right)$ & 2977 & 11 & 1579 & 2913 & 13 & 97 \\
\hline $\operatorname{TSS} \quad\left(\mathrm{mg} 1^{-1}\right)$ & 564 & 10 & 158 & 677 & 12 & 211 \\
\hline $\operatorname{VSS} \quad\left(\mathrm{mg} \mathrm{l}^{-1}\right)$ & 308 & 10 & 137 & 260 & 12 & 182 \\
\hline
\end{tabular}

$\mathrm{n}$ : number of samples; s: standard deviation

Analytical - methods. pH, alkalinity, total and volatile solids (TS,TVS), total and volatile suspended solids (TSS, VSS), total and soluble Chemical Oxygen Demand (COD), Biochemical Oxygen Demand $\left(\mathrm{BOD}_{5}\right)$ and ammonium $\left(\mathrm{N}-\mathrm{NH}_{4}{ }^{+}\right.$) were measured according to standard Methods (15) with the following frequency: pH, alkalinity and total COD, twice a week; soluble COD, TS, TVS, TSS, VSS and ammonium, once a week; effluent $\mathrm{BOD}_{5}$ was analysed three times during steady state periods. Gas production was obtained by water displacement and methane content was measured with gas chromatography using a thermal conductivity detector (16)

\section{RESULTS AND DISCUSSION}

Sedimentation of the wastewater resulted in a reduction of 37\% of COD and 70\% of TSS. Terephthalic acid has a high specific gravity (1.5) and low solubility in water (19 mg $\left.1^{-1}, 25^{\circ} \mathrm{C}\right)$. As mentioned, settling prior to feeding was done at the pH of raw influent (4.5). Kun et al. (17) showed that precipitation of terephthalic acid begins at $\mathrm{pH}$ 5.1, it is almost complete at $\mathrm{pH} 4.5$ and total separation is accomplished at $\mathrm{pH} 3.86 \quad\left(\mathrm{pK}_{1}=3.54\right.$, $\left.\mathrm{pK}_{2}=4.46\right)$. Thus, in our case, it can be expected that most 
of PTA is in the settled solids, only a fraction remaining in a near colloidal form (particle size around $5 \mu \mathrm{m}$ according to Kun et al. (17), and measured as a part of the influent VSS (see Table 2).

The effluent total COD curve (Fig. 2) permits us to identify transient and steady state periods. The latter occurred during days 73 to 87 and 145 to 164 , corresponding to the two HRT applied. The former, besides the start-up, were present in day 48 (shock load), in days 104 to 115 and 134 to 138 (no substrate feeding) and during days 88 to 144 and 165 to 178 (change in feed rate). Fig. 2 also presents the COD removal efficiency and the daily gas production during the whole experimental period.

\section{start-up}

At the beginning, there was no gas production, although some COD removal efficiency was achieved. The initial diluted content of the reactor, together with the low feed rate applied during the first three weeks, seem to be partially responsible for this result. Another reason is VSS retention in the reactor by physical means; in this period, the VSS removal efficiency was $61 \%$ and the influent had a higher VSS content (788 $\left.\mathrm{mg} \mathrm{l}^{-1}\right)$.

Gas production started at day 38, and increased markedly from day 50 to day 73, when more regular daily gas volumes were obtained. The start-up was long, considering that the reactor had already a well-established biofilm. Of course, an acclimation period could be expected due to substrate change, from acetic and propionic acids (14) to the petrochemical influent, but the delay in gas production suggests that, at first. the new substrate was difficult to be degraded anaerobically.

\section{Steady state}

Day 73 was taken as the beginning of the first steady state, corresponding to a HRT of 5.8 days and an organic load of $1.08 \mathrm{~kg} \mathrm{COD} \mathrm{\textrm {m } ^ { - 3 }} \mathrm{d}^{-1}$ (Fig. 2, day 73 to 87). The second steady state, for a HRT of 3.4 days and a load of $1.89 \mathrm{~kg} \operatorname{COD~m^{-3}} \mathrm{d}^{-1}$, was reached in day 145 and it was maintained until day 164. Table 3 contains data from both periods. 

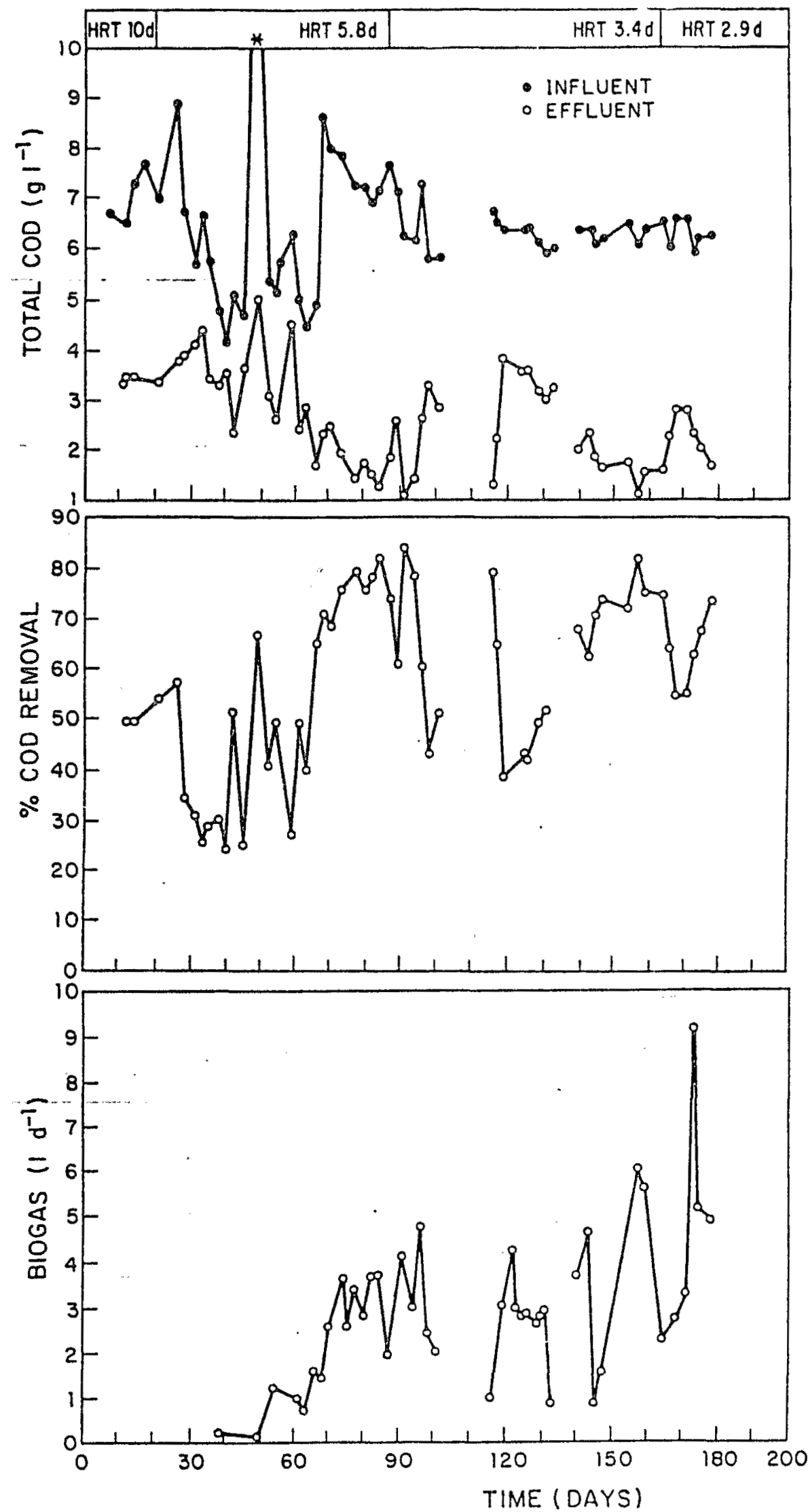

Fig. 2 Evolution of influent and effluent COD, COD removal efficiency, and biogas production. (*) shock load. 
The COD removal efficiencies for both HRT are considerably higher than those obtained in a previous study (13) with UASB reactors and the same wastewater. In that work, the efficiency was $46.4 \%$ in the best case, with an organic load of $2.6 \mathrm{~kg}$ COD m $\mathrm{d}^{-1}$ (HRT 2.7 days) and a gas production of $0.47 \mathrm{~m}^{3} \mathrm{~m}^{-3} \mathrm{~d}^{-1}$ (NTP) with $61 \%$ of $\mathrm{CH}_{4}$.

Table 3. Characterization of the steady state periods

\begin{tabular}{|c|c|c|}
\hline & HRT $5.8 \mathrm{~d}$ & HRT $3.4 \mathrm{~d}$ \\
\hline 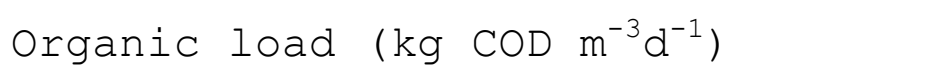 & 1.08 & 1.89 \\
\hline 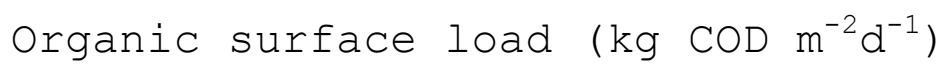 & 4.78 & 8.4 \\
\hline COD removal efficiency Total (음) & 77.4 & 74.5 \\
\hline COD removal efficiency soluble ( $\%$ ) & 77.5 & 73.0 \\
\hline TSS removal efficiency $\left(\frac{\circ}{0}\right)$ & 27.3 & 33 \\
\hline VSS removal efficiency ( $\left(\frac{0}{0}\right)$ & 24.0 & $\mathrm{n} \cdot \mathrm{d}$ \\
\hline Gas production $\left(\mathrm{Nm}^{3} \mathrm{~m}^{-3} \mathrm{~d}^{-1}\right)$ & 0.46 & 0.63 \\
\hline $\mathrm{CH} 4$ yield $\left(\mathrm{Nm}^{3} \mathrm{CH}_{4} \quad \mathrm{~kg}^{-1} \mathrm{COD}\right.$ removed $)$ & 0.36 & $\mathrm{n} \cdot \mathrm{d}$ \\
\hline $\mathrm{CH}_{4}$ content ( $\left(\frac{\circ}{0}\right)$ & 62 & $n \cdot d$. \\
\hline
\end{tabular}

n.d. not determined

For a more direct comparison with the results in Table 3, data obtained with a UASB reactor operated at 3.2 days of HRT and an organic load of $2.2 \mathrm{~kg}$ COD m $\mathrm{m}^{-3} \mathrm{~d}^{-1}$ were (13): COD removal efficiency of $43.9 \%$, gas production of $0.35 \mathrm{~m}^{3} \mathrm{~m}^{-3} \mathrm{~d}^{-1}$ (NTP) and 63\% $\mathrm{CH}_{4}$. The tubular fixed film reactor was much better than the UASB reactor in treating this particular wastewater. In order to explain this fact, the following considerations must be taken into account:

First, the biomass content was very different in both reactors: $30 \mathrm{~g}$ VSS for the UASB and $100.2 \mathrm{~g}$ VSS for the tubular reactor: this last value was estimated by subtracting the drained volume $(2.5$ 1) from the void reactor volume $(4.75 \mathrm{l})$ and applying a biofilm density of $0.116 \mathrm{~kg}$ VSS $\mathrm{m}^{-2}$ for a $2.6 \mathrm{~mm}$ biofilm thickness (18). Thus, the organic specific load applied to the UASB $(0.38$ $\mathrm{kg}$ COD $\mathrm{kg}^{-1} \mathrm{VSS} . \mathrm{d}^{-1}$ ) was higher than the estimated load for the tubular reactor $(0.09)$. However, when operated at 0.10 $\mathrm{kg} C O D \mathrm{~kg}^{-1} \mathrm{VSS} . \mathrm{d}^{-1}$, the UASB reactor only reached $34 \%$ of COD removal (13). Second, the biomass in a tubular reactor is distributed in its entire volume, while in a UASB 
reactor, the sludge is located in the bottom, forming a sludge blanket. For an influent with toxic or inhibitory compounds, which may be in the form of TSS, a UASB will be more affected than a fixed film reactor. In this respect, there is evidence that the terephthalic acid plant wastewater may have a toxic effect on groundwater microorganisms, even in moderate concentrations (19). Moreover, a test in serum bottles (13) showed a total inhibition of methanogenesis with the same wastewater utilized in our work $\left(0.56 \mathrm{~g}\right.$ COD $\left.\mathrm{g}^{-1} \mathrm{VSS}\right)$, as well as with terephthalic acid $\left(0.23 \mathrm{~g}^{-1} \mathrm{VSS}\right)$. As mentioned, the influent VSS contained this acid, so a toxic concentration could have been reached by accumulation in the sludge blanket.

The methane yield obtained with the tubular reactor during the first HRT is very close to the stoichiometric value $(0.35)$ : this suggests that the COD removed was actually converted to methane, and no accumulation of influent organic matter occurred. Apparently, the arrangement of support, the distribution of biomass and the hydraulic characteristics of the tubular reactor favoured hydrolysis of the influent VSS and conversion of soluble substrates to methane, reducing wastewater potential toxicity.

\section{Transient state}

An organic shock load of $15000 \mathrm{mg}$ COD $\mathrm{l}^{-1}$ (2.4 times the normal load) was accidentally applied to the reactor in day 48. The effluent COD raised rapidly over $5000 \mathrm{mg} \mathrm{l}^{-1}$ (Fig. 2) and the COD removal efficiency dropped under 30\%. The fact that this occurred during the start-up period, does not permit the proper evaluation of the shock effects. Anyway, it seems that by day 60, the reactor had recovered as suggested by the effluent COD curve.

The change of feed rate (day 88) from HRT of 5.8 days to HRT of 3.4 days, corresponds to an increase of 1.8 times the original organic load. The effluent COD raised quickly from day 91 (Fig. 2), but feeding stopped from day 104 to 115 due to technical problems in wastewater supply; during this period, the decrease in reactor COD was caused by batch conditions. When feeding was restored, the effluent COD increased sharply, but almost immediately the COD declined toward the new steady state. Apparently, the feed stop was not responsible for the high effluent COD in day 119, which was caused by the HRT change, and only retarded 
the normal reactor response. This may be confirmed by a second feed stop of five days (134 to 138), which did not affect the reactor. This agrees with the well known resistance of anaerobic fixed film reactors to periods without feeding.

A second HRT change was applied in day 165 (3.4 days to 2.9 days of HRT), but only limited data were obtained because the wastewater supply stopped. Nevertheless, the short period of operation under the new conditions (two weeks) permitted us to follow the effluent COD response, which was similar to the one observed in the previous HRT modification. Apparently, the reactor was rapidly approaching the COD removal efficiencies obtained in the former steady states, so the optimum HRT may well be shorter than three days)

\section{Anaerobic-aerobic treatment process as an alternative to the conventional aerobic treatment}

Based on our results, the treatment of terephthalic acid plant wastewater cannot be accomplished by an anaerobic process alone, since the suspended solids in the raw wastewater would cause clogging and accumulation of toxic compounds in the reactor (13). A settling operation prior to an anaerobic tubular fixed film reactor would eliminate this problem. A comparison between this process arrangement and the aerobic treatment of a terephthalic acid plant synthetic effluent (3) is shown in Table 4.

As mentioned, the HRT of 3.4 days could have been further reduced without affecting the anaerobic COD removal efficiency. In addition, nearly 70\% of the synthetic wastewater COD was in the form of easily biodegradable compounds (methanol and acetic acid), which was not the case for the actual effluent employed in this study. The former considerations led us to think that the anaerobic treatment of the settled influent can be realized at the same HRTs employed in the aerobic treatment. Nevertheless, it appears that aerobic treatment reaches higher removal efficiencies. but it needs important energy input, due to the high influent COD concentration. In contrast, the anaerobic process produces a significant amount of energy ( $2.8 \mathrm{kWh} \mathrm{kg}^{-1} \mathrm{COD}$ fed) which may be converted to electrical energy (around $0.55 \mathrm{kWh} \mathrm{kg}^{-1} \mathrm{COD}$ fed). Furthermore, if a primary settler is added prior to the anaerobic reactor, the VSS removal increases the global COD removal 
efficiency to $84 \%$. Of course, the disposal of the primary sludge must be considered.

It should be noted that the fate of the influent TSS in the aerobic conventional process is not known. Adsorption of organic compounds on activated sludge has been reported (20). In our case, there is evidence of terephthalic acid toxicity on anaerobic bacteria, which may not be the case for aerobic microorganisms. The primary sludge adsorption on aerobic flocs or its sedimentation in the secondary settler may be a way of removing it, in case it is not biodegraded.

Table 4. Comparison between two process configurations for terephthalic acid plant wastewater treatment

\begin{tabular}{|c|c|c|c|c|c|}
\hline $\begin{array}{l}\text { Process } \\
\text { configuration }\end{array}$ & $\begin{array}{l}\text { HRT } \\
\text { (d) }\end{array}$ & $\mathrm{COD}$ & $\begin{array}{l}\text { removal } \\
\frac{\circ}{\circ}\end{array}$ & $\begin{array}{l}\text { Energy balance } \\
\text { (kWh } \mathrm{kg}^{-1} \mathrm{COD} \text { fed) }\end{array}$ & Ref. \\
\hline $\begin{array}{l}\text { Aerobic } \\
\text { (synthetic } \\
\text { WW }^{*} \text { ) }\end{array}$ & 2 & & $>90$ & $(-) 0.62$ & 3 \\
\hline $\begin{array}{l}\text { Primary } \\
\text { settling + } \\
\text { anaerobic } \\
(\text { raw ww*) }\end{array}$ & 3.5 & & 84 & $(+) 0.55$ & $\begin{array}{l}\text { This } \\
\text { work }\end{array}$ \\
\hline
\end{tabular}

WW* $^{\star}$ wastewater

$(-)$ energy consumed

$(+)$ energy produced considering a 20\% conversion efficiency from chemical to electrical energy.

The anaerobic reactor effluent can be further treated with an aerobic process, its COD/BODs ratio being 1.6 . In this configuration, the primary sludge could be fed to the aerobic system, as it is actually done in the conventional process, and the energy produced by the anaerobic pretreatment should cover the needs of the aerobic postreatment unit, resulting in a highly efficient, no energy consuming process.

\section{CONCLUSIONS}

The downflow anaerobic tubular fixed film reactor was successful in treating primary settled terephthalic acid plant wastewater: at a HRT of 3.4 days, it reached a $75 \%$ 
COD removal efficiency.

The low organic load applied $\left(1.9 \mathrm{~kg} C O D \mathrm{~m}^{-3} \mathrm{~d}^{-1}\right)$ shows that the petrochemical effluent has slow anaerobic degradation kinetics. It may be confirmed by the long acclimation period required for reactor start-up.

The apparent inhibitory characteristic of the wastewater, present in a previous UASB reactor study, did not affect the tubular reactor. The different biomass distribution patterns for both types of reactors may explain this fact. In addition, the tubular reactor had good resistance to shock loads and to periods without feeding.

A primary settling tank followed by an anaerobic - aerobic treatment process may be an attractive, energy saving option to the three stage aerobic process commonly used.

\section{ACKNOWLEDGEMENTS}

Partial financial support was obtained from the Organization of American states (OAS) and European Economic Community (EEC). We thank E. Castillo for valuable technical assistance and $M$. del Villar for his support and interest in this study. This work is part of two collaboration research programs between the Institut Français de Recherche Scientifique pour le Développement en Cooperation (ORSTOM) and the Instituto de Ingeniería UNAM with the Universidad Autónoma Metropolitana Iztapalapa.

\section{REFERENCES}

1. A.G. Bemis, J.A. Dindorf, B. Horwood and C. Samans, in Kirk Othmer Encyclopedia of Chemical Technology, F.M. Herman, D.F. Othmer, C.G. Overberg, G.T. Seaborg, M. Grayson and D. Eckroth, ed., John Wiley and Sons, New York, 1982, Vol.17, 746-758.

2. Inf. Chimie, 278, 209-215 (1986).

3. C.M. Lau, Proc. 32 $2^{\text {nd }}$. Ind. Waste Conf., Purdue Univ., Ann Arbor Science, Ann Arbor, 1978, 63-74.

4. F.A. Lund and D.S. Rodriguez, J. Gen. Appl. Microbiol., $30,53-61(1984)$.

5. S. Brugnaro and B. Polo, Inquin., 27, 65-68 (1985). 
6. M.T. Suidan, J.T. Pfeffer and G.F. Nakhla, Anaerobic Digestion 1988, Proc. 5th Int. Symp., E.R. Hall and P.N. Hobson ed., Pergamon Press, 1988, 249-257.

7. L.H, Nel, J. De Haast and T.J. Britz, Biotechnol. Lett. , 6, 741-746 (1984).

8. F. Edeline, G. Lambert and H. Fatticcioni, Process Biochem., 4, 58-60 (1986).

9. P. Vogel and J. Winter, in Poster Papers, $5^{\text {th }}$ Int. Symp. Anaerobic Digestion, A. Tilche and A. Rozzi ed., Monduzzi editore, Bologna, 1988, 689-694.

10. P. Sanna, Anaerobic Digestion 1988, Proc. $5^{\text {th }}$ Int. Symp., E.R. Hall and P.N. Hobson ed., Pergamon Press, $1988,487-489$.

11. A.J.M.L. Borghans and A. Van Driel, in Poster Papers, $5^{\text {th }}$ Int. Symp. Anaerobic Digestion, A. Tilche and A. Rozzi ed., Monduzzi editore, Bologna, 1988, 627-630.

12. J.A. Leenheer, R.L. Malcolm and W.R. White, Environ. Sci. Technol., 10, 445-451 (1976).

13. J.P. Guyot, H. Macarie and A. Noyola, Appl. Biochem. Biotechnol.. in press.

14. O. Monroy, A. Noyola, F. Ramirez and J.P. Guyot, in Poster Papers, 5th Int. Symp. Anaerobic Digestion A. Tilche and A. Rozzi ed., Monduzzi editore, Bologna, 1988, $747-751$.

15. APHA, AWWA and WPCF, Standard Methods for the Examination of Water and Wastewater, $15^{\text {th }}$ edition, Washington D.C., 1980 .

16. A. Noyola, B. Capdeville and H, Roques, Water Res., $22,1582-1592,1988$

17. X. Kun, X. Liangcai, D. Huiru, S. Jianhua and Z. Qiubo, Water Treat., 3, 481-490 (1988).

18. L. van den Berg and C.P. Lentz, in Proc. $34^{\text {th }}$ Ind. Waste Conf., Purdue Univ., Ann Arbor Science, Ann Arbor, $1980,319-325$. 
19. J.A. Leenheer, R.L. Malcolm and W.R. White, Physical, Chemical and Biological Aspects of Subsurface Organic waste injection near Wilmington, N.C. Geoloqicai Survey Professional Paper 987, U.S. Government Printing Office, Washington D.C., 1976, 51 pp.

20. A.C. Petrasek, I.J. Kugelman, B.M. Austern, T.A. Pressley, L.A. Winslow and R.H. Wise, J. Water Pollut. Control Fed., 55. 1286-1296 (1983) 